\title{
Participation of Tribal Women in the Developmental Programmes for their Livelihood Security
}

\author{
P. Mareeswaran ${ }^{1 *}$, R. Jansirani ${ }^{2}$, M. Asokhan, K. Mani ${ }^{3}$ and M.R. Duraisamy ${ }^{4}$ \\ ${ }^{1}$ Department of Agricultural Extension and Rural Sociology, ${ }^{2}$ Department of Sustainable Organic \\ Agriculture, ${ }^{3}$ Department of Agricultural Economics, ${ }^{4}$ Department of Physical Science and \\ Information Technology, TNAU, Coimbatore, India \\ *Corresponding author
}

\begin{tabular}{|c|c|}
\hline & A B S T R A C T \\
\hline $\begin{array}{l}\text { Participation, } \\
\text { Tribal Women, } \\
\text { Developmental } \\
\text { Programmes, } \\
\text { Livelihood } \\
\text { Security. }\end{array}$ & \multirow{3}{*}{ 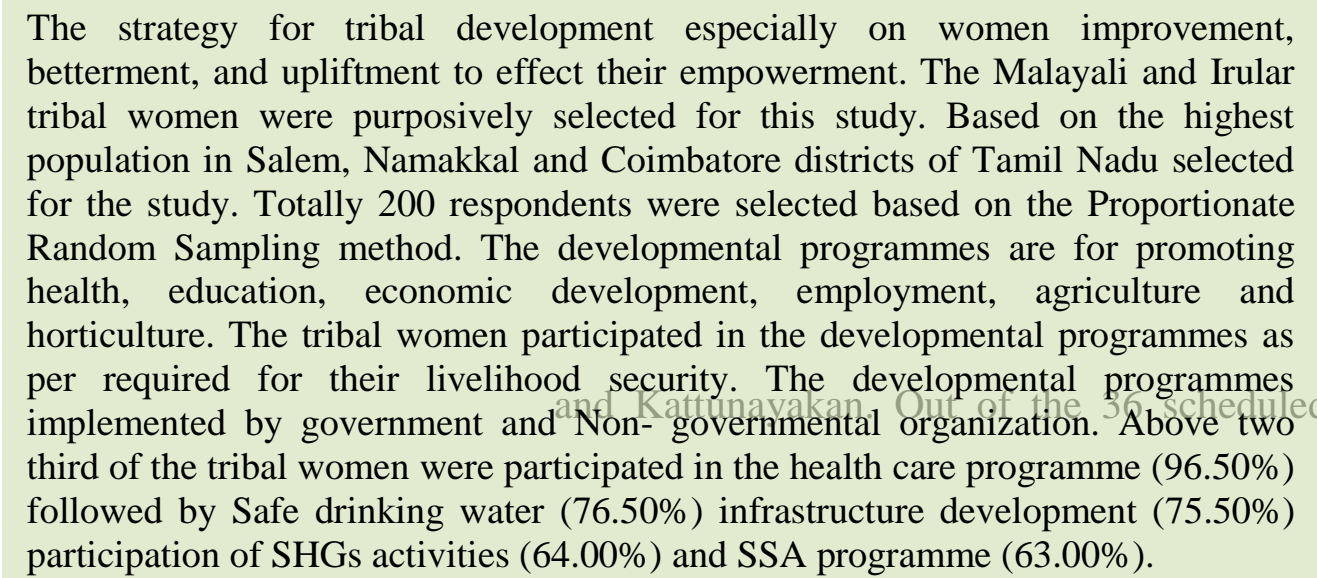 } \\
\hline Article Info & \\
\hline $\begin{array}{l}\text { Accepted: } \\
\text { 19 April } 2017 \\
\text { Available Online: } \\
10 \text { May } 2017\end{array}$ & \\
\hline
\end{tabular}

\section{Introduction}

The tribal population is identified as the aboriginal inhabitants of our country. For centuries, they have been living a simple life based on the natural environment and have developed cultural patterns congenial to their physical and social environment. References of such tribal groups are found even in the literature on the ancient period, right from the Ramayana and the Mahabharata periods (Mehta, 2000). There are 36 Tribal Subcommunities in the state including 6 particularly Vulnerable Tribal Groups (PTGs) viz., Toda, Kota, Kurumbas, Irular, Paniyan tribes (ST), Malayali, Irular, Kattunayakan, Kurumans and Kondareddies together constitute $85.3 \%$ of the ST population of the state. Malayali's are the largest tribal group with a population of 310,042 constituting $47.6 \%$ of the state ST population (census of India, 2011). The areas where the population of Scheduled Tribes exceeds $50 \%$ of the total population are designed as "Integrated Tribal Development Programmes Areas (ITDP)" in 7 districts of the state. Those districts are: Salem, Namakkal, Villupuram, 
Thiruvannamalai, Dharmapuri and Vellore.

Thiruchirapalli,

However, tribal women face problems and challenges in getting a sustainable livelihood and a decent life due to environmental degradation and the interference of outsiders, the strategy for tribal development especially on women improvement, betterment, and upliftment to effect their empowerment. Tribal women have adjusted themselves to live a traditional life style in the local environment and occupations based on natural resources.

In the light of the above, the planners and policy makers have to evolve suitable strategies and formulate relevant policies to enhance the speed of tribal development. This obviously entails a clear understanding of the socio-cultural of tribal life, the participation in developmental programmes for their livelihood security.

\section{Materials and Methods}

The study was conducted in Salem, Namakkal and Coimbatore districts of Tamil Nadu were purposively selected based on the percentage of tribal population and available more number of beneficiaries in the study areas. Each district, one block was purposively selected based on maximum availability of Malayali and Irular tribes.

Ex-post facto research design was used for the study. Totally 200 respondents of tribal women were interviewed for the study. The number of respondents from each of the selected block was fixed based on the Proportionate Random Sampling (PRS) method. The data were collected with well structured pretested interview schedule. The collected data were analyzed and interpreted with percentage analysis.

\section{Results and Discussion}

\section{Social development}

The above table (Table 1.) inferred that majority 76.50 per cent of the tribals participated in safe drinking water programme, followed by 75.50 per cent of the respondents participated in infrastructure development. Meager 16.00 per cent of the respondents participated in village resource development works and communication development programmes. Due to inadequate skill less participation of tribals in establishment of community centers. This finding is in line with the findings of Bharathi Dhevi (2014) and Jayakumar (2016).

\section{Health}

The health considered as sensitive one because health developmental programmes very important for tribal women those who are settled in hills. The above table (Table 1.) revealed that most of the respondents 96.50 per cent participated in health care programme. Hygiene is very important thing for good health followed by 26.50 per cent of the respondents expressed in hygiene and sanitation programme. The rest of the respondents participated in maternal malnutrition and awareness on sickle cell anemia 26.00 per cent and 21.00 per cent due to aware of nutritional value and importance of medicines.

\section{Education}

The above table (Table 1.) revealed that majority 63.00 per cent of the respondents participated in SSA programme, followed by 29.50 per cent of respondents mainly focused and participated in free educational programme, very less 10.00 per cent participation in special coaching classes for competitive examination due to unaware of job opportunities from government sectors. 
This finding is line with the support of Singha and Baruah (2011).

\section{Economic development}

The saving habits always useful to precaution from financial crisis (Table 1.). This study reported that two third of respondents 19.50 per cent participated in bank savings. Meager 9.50 per cent of the respondents participated in business activities like petty shop, tailoring and forest produce selling. Rest of the respondents participated in marketing developmental programmes for tribal products and monetary income from NWFP 7.00 per cent and 5.50 per cent of the respondents respectively. This finding is derive the support from the findings of Sujeetha (2012).

\section{Employment}

The employment which is most powerful upliftment of living standard of the people, hence half of the respondents 34.50 per cent participated in income generation programme for self employment and their livelihood security, followed by 28.50 per cent of the respondents expressed in skilled training programme for tribal women to conserve the traditional handicrafts. Meager 19.50 per cent of the respondents participated in offered local specific training programme implemented by government and Nongovernmental organization for improving their living standard through self employment.

Table.1 Distribution of respondents according to their participation in developmental programmes

\begin{tabular}{|c|l|c|c|}
\hline \multicolumn{1}{|c}{ Developmental programmes } & No & Per cent \\
\hline S. No. & \multicolumn{1}{|c|}{200} \\
\hline I. & Social development & 151 & 75.50 \\
\hline 1. & Infrastructure development & 153 & 76.50 \\
\hline 2. & Safe drinking water & 32 & 16.00 \\
\hline 3. & Village resource development works & 26 & 15.47 \\
\hline 4. & Establishment of community centre & 32 & 16.00 \\
\hline 5. & Communication developmental programmes & & \\
\hline II. & Health & 193 & 96.50 \\
\hline 1. & Health care programme & 52 & 26.00 \\
\hline 2. & Maternal malnutrition programme for tribal women & 53 & 26.50 \\
\hline 3. & Hygiene and sanitation programme & 42 & 21.00 \\
\hline 4. & Awareness programmes on Sickle Cell Anaemia & & \\
\hline III. & Education & 59 & 29.50 \\
\hline 1. & Free educational programme & 126 & 63.00 \\
\hline 2. & SSA programme & 20 & 10.00 \\
\hline 3. & Special coaching classes for competitive examination & & \\
\hline IV. & Economic development & 39 & 19.50 \\
\hline 1. & Bank savings & 11 & 5.50 \\
\hline 2. & Monetary income from NWFP & 19 & 9.50 \\
\hline 3. & Participation in business activities & 14 & 7.00 \\
\hline 4. & Marketing developmental programmes for tribal products & & \\
\hline
\end{tabular}

* Multiple responses 
Table.2 Distribution of respondents according to their participation in developmental programmes

\begin{tabular}{|c|l|c|c|}
\hline \multicolumn{1}{|c|}{ Developmental programmes } & No & Per cent \\
\hline S. No. & \multicolumn{1}{|c|}{${ }^{*}$} \\
\hline V. & Employment & & \\
\hline 1. & Income generation programme for self employment & 69 & 34.50 \\
\hline 2. & $\begin{array}{l}\text { Skilled training programme for tribal women to conserve the } \\
\text { traditional handicrafts making }\end{array}$ & 57 & 28.50 \\
\hline 3. & Offered local specific training programme & 39 & 19.50 \\
\hline VI. & Agriculture & & \\
\hline 1. & Demonstration on modern practices & 40 & 23.80 \\
\hline 2. & Vermicompost unit & 15 & 7.50 \\
\hline 3. & Bee keeping & 11 & 5.50 \\
\hline 4. & Goat rearing & 30 & 15.00 \\
\hline 5. & Cattle rearing & 14 & 7.00 \\
\hline VII. & Horticulture & & \\
\hline 1. & Planting of medicinal plants & 13 & 6.50 \\
\hline 2. & $\begin{array}{l}\text { Participation in training value addition of fruits,vegetables and } \\
\text { medicinal plants }\end{array}$ & 15 & 7.50 \\
\hline 3. & Participation in study tours & 10 & 5.00 \\
\hline & Non-governmental organization developmental programmes & & \\
\hline 1. & Vocational training & 63 & 31.50 \\
\hline 2. & Health camp & 186 & 93.00 \\
\hline 3. & Medicinal plant cultivation & 20 & 10.00 \\
\hline 4. & Participation in SHG activities & 128 & 64.00 \\
\hline 5. & Marketing agricultural produce & 10 & 5.00 \\
\hline 6. & Value addition of millets & 13 & 6.50 \\
\hline 7. & Value addition of forest produce & 11 & 5.50 \\
\hline 8. & Infrastructure development & 28 & 21.00 \\
\hline 9. & Natural resource conservation & 55 & 27.50 \\
\hline 10. & Volunteer group activities & & \\
\hline$*$ Multiple & responses & & \\
\hline
\end{tabular}

* Multiple responses

\section{Agriculture}

The agriculture which is linchpin of conserves the traditional culture and backbone of the nation, done by the women. The study inferred that one third of the respondents 23. 50 per cent participated in demonstration on modern practices, followed by Goat rearing 15.00 per cent of the respondents participated (Table 2.), the lack of adequate skills about honey bee rearing less participation in bee keeping 5 . 50 per cent of the respondents respectively, this result coincides with the findings derived by Arularasan (2010).

\section{Horticulture}

The study revealed that one fourth of respondents 7.50 per cent participated in training value addition of fruits, vegetables and medicinal plants, followed by 6.50 per cent of the respondents participated in planting of medicinal plants (Table 2.). The rest of the respondents 5.00 per cent participated in study tours for getting exposure related to horticulture and allied activities. This finding is derive the support from the findings of Sakeer Husain (2010). 


\section{Non-governmental developmental programmes}

The Non-governmental organization offered so many developmental programmes for empowerment of tribal women for their livelihood security. The study inferred that majority (93.00 per cent) of the respondents participated in health camp, followed by 64.00 per cent of the respondents participated in SHG activities (Table 2.). Meager 31.50 per cent of the respondents participated in vocational training. The rest of the respondents participated in value addition of millets and value addition of forest produce 6.50 per cent and 5.50 per cent. This finding is in line with the findings of Indumathi (2013) and Nisha (2013).

It is concluded that the developmental programmes were support to empowerment of tribal women those who are settled in kolli hills, kalrayan hills and food hills in Coimbatore district of Tamil Nadu. The developmental programmes were mentioned promoting health, education, economic development, employment, agriculture and horticulture. Above half of the tribal women's are utilized the developmental programmes which are implemented by government and Non-governmental organization and participated in developmental programmes for their livelihood security.

\section{References}

Arularasan, G.S. 2010. A critical analysis of tribal development programmes in

\section{How to cite this article:}

Mareeswaran, P., R. Jansirani, M. Asokhan, K. Mani and Duraisamy, M.R. 2017. Participation of Tribal Women in the Developmental Programmes for their Livelihood Security. Int.J.Curr.Microbiol.App.Sci. 6(5): 2181-2185. doi: https://doi.org/10.20546/ijcmas.2017.605.245
Western Ghats of south India. Ph.D. Thesis, University of Agricultural Sciences, Bengaluru, KARNATAKA (India).

Bharathi Dhevi, V.R. and Bhooma Mani. 2014. Demographic Profile of Selected Irular Tribes of Coimbatore District Tamil Nadu. Int. J. Sci. Res. Publ., 4(1): 1-8.

Indumathi, K. 2013. Impact of development programmes on livelihood security of Tribes. Unpub, Ph.D. Thesis, TNAU, Coimbatore.

Jayakumar, A. and P. Palaniyammal. 2016. Socio-Economic status of scheduled tribes in Kalrayan hills. Int. J. Res.

Mehta. 2000. Globalization, displacement and the livelihood issues of tribal and agriculture dependent poor people. $J$. Developing Soc., 25(4): 457-480.

Nisha, R. 2013. Participation of tribal women in development programmes - A sociocultural analysis. Unpub. M.Sc (Ag.) Thesis, TNAU, Coimbatore.

Sakeer Husain, A. 2010. Knowledge, adoption and perceived effectiveness of Indigenous Horticultural Practices in Kerala. Ph.D.thesis, GRI (DU), Gandhigram.

Singha, A.K. and M.J. Baruah. 2011. Farmers' adoption behaviour in rice technology: An analysis of adoption behaviour of farmers in rice technology under different farming systems in Assam. $J$. Hum. Ecol., 35(3): 167-172.

Sujeetha, T.N. 2012. Empowerment of tribal women through SHGs- An analysis. Unpub. M.Sc. (Ag.) Thesis, \& RI, TNAU, Coimbatore. Granthaalayah, 4(3): 22-30. 